\title{
ГЕРМИНАТИВНЫЕ ОПУХОЛИ ГОНАД: ОПИСАНИЕ КЛИНИЧЕСКОГО СЛУЧАЯ ДИСГЕНЕЗИИ ГОНАД С ОДНОСТОРОННЕЙ ГОНАДОБЛАСТОМОЙ
}

\author{
М.С. Панкратова, С.Р. Еникеева, М.А. Карева \\ ФГБУ «Национальный медицинский исследовательский центр эндокринологии» Минздрава \\ России, Москва.
}

ВВЕДЕНИЕ: У пациенток с синдромом Шерешевского-Тернера наличие в кариотипе материала Ү-хромосомы рассматривается в качестве фактора риска опухоли гонад из герминативных клеток: гонадобластомы и дисгерминомы. Согласно международным и отечественным рекомендациям, при такой форме дисгенезии гонад рекомендовано их удаление, дополнительно обсуждаются многократно возрастающие риски малигнизации дисгенетичной ткани гонад на фоне применения заместительной гормональной терапии.

ОПИСАНИЕ КЛИНИЧЕСКОГО СЛУЧАЯ. Пациентка вПервые была консультирована У эндокринолога по месту жительства в возрасте 15,8 лет с жалобами на низкий рост и отсутствие менструаций. При осмотре наблюдалась задержка роста (SDS роста $=-2,5$ ), допубертатное половое развитие. В гормональном профиле выявлен гипергонадотропный гипогонадизм - ЛГ $30 \mathrm{ME} / л$, ФСГ $125 \mathrm{ME} / л$, на УзИ малого таза — гипоплазия матки, придатки не визуализировались.

Пациентке было проведено кариотипирование, выявлена маркерная хромосома: $46, X+\operatorname{mar}(38) / 45, X(5)$ (моносомия X, сверхчисленная маркерная хромосома, мозаичная форма). Для уточнения кариотипа было проведено молекулярно-генетическое исследование (FISH-методом) в ФГБНУ «МГНЦ» на два хромосомных локуса (DZX1, DYZ3). Выявлено, что маркерная хромосома является кольцевой хромосомой Y (ish r(Y)(DXYS130-, DYZ3+, SRY+), кариотип определен как мозаичный, 45,X[130]/46,X,r,(Y) [70]. При дообследовании по месту жительства уровни онкомаркеров (АФП, ХГЧ) в пределах референса. МРТ малого таза- гипоплазия матки и придатков (гонады $8 \times 5$ мм, без фолликулов).

После проведенного обследования, по рекомендации гинеколога по месту жительства в течение 1,5 мес получала эстрадиола валериат 0,5 мг/сут с целью индукции пубертата. Терапия была срочно отменена после консультации эндокринолога, пациентка направлена на лапароскопическую гонадэктомию. В возрасте 17 лет пациентке было проведено оперативное вмешательство в ФГБУ «Эндокринологический научный центр», удалены стрек-гонады, представленные тяжами длиной 2,5 см, с прилежащими маточными трубами.

По данным патоморфологического исследования операционного материала гонад: левая гонада представлена зачатком маточной трубы и прилежащей к маточной трубе тканью гонады с признаками дисгенезии, на фоне которых микроочаг гонадобластомы. Правая гонада представлена зачатком маточной трубы с прилежащей тканью гонады с признаками дисгенезии: фрагмент стромы яичника с прилежащими извитыми канальцами яичка и скопление клеток типа клеток Лейдига. Патоморфологическое заключение: Гонадобластома левой гонады на фоне дисгенезии гонад.

Пациентка была дообследована у онколога, данных за распространенность опухолевого процесса получено не было. Через 4 мес, с разрешения онколога, девочке была назначена заместительная гормональная терапия.

ЗАКЛЮчЕНИЕ: Описан клинический случай пациентки с мозаичным кариотипом с кольцевой У-хромосомой и односторонней гонадобластомой на фоне дисгенезии гонад. Представленная картина наглядно демонстрирует необходимость дополнительного исследования кариотипа при наличии маркерных хромосом, а также необходимую тактику дальнейшего лечения при выявлении в кариотипе клона с Y-хромосомой. 